\title{
Can Loyalty be extended to Airlines? An Inquisition from Air Passengers
}

\begin{abstract}
By Sam Sarpong ${ }^{*}$
Airlines have always sought to engage with passengers by resorting to customer loyalty programmes. The exigency for this is that customers drive businesses and loyalty constitutes a means to sustainable business. The loyalty programmes by airlines has been a driving force behind customer loyalty since the early 1980s. The study uses a narrative inquiry to explore the extent to which passengers have become acquainted with it. It also examines whether passengers can be loyal to airlines and under what conditions this can prevail. Its findings suggest that although air passengers are prepared to forge closer ties with the airlines, they often see the airlines as reneging on their pledge to offer reciprocal terms of this loyal arrangement.
\end{abstract}

Keywords: customer loyalty, airlines, frequent flyer, passengers, reward systems

\section{Introduction}

The competitive landscape of the global airline industry has been in a constant change in recent years (Wegner et al. 2012). Uncertainty in the marketplace, high fuel costs, environmental concerns, dwindling passenger numbers and other issues have seriously affected the fortunes of the industry (Sentance 2012). Airlines have, thus, been under increasing pressure to demonstrate superior services through innovative schemes in order to attract more passengers (Zuidberg 2014). Aside from the recent developments, the Covid-19 pandemic, which has engulfed the world, has also added to the already disturbing fate of the airline industry (Pascual and Cain 2021, Maneenop and Kotcharin 2020).

With many aviation sources presenting a grim situation for the airline industry, airlines are now striving to turn the industry around (Deloitte 2020). This has spurred them to initiate various means to optimise, strengthen and scale up plans to help the airline industry to get back on track. Incidentally, one of the areas opened to the industry is creating innovative strategies for customer loyalty (Pascual and Cain 2021). As such, loyalty programmes, a marketing strategy which is used to attract and retain business, have become very popular within the airline industry of late (Deloitte 2020). Through these loyalty programmes, companies are able to create some value by motivating new and existing customers (Reichheld and Sasser 1990).

But with 'loyalty' remaining a seemingly ill-defined concept, the need to explore what it is and the gains that parties in this arrangement can derive from it, seems quite essential. For instance, it is important to know whether loyalty programmes ensure a win-win situation for both passengers and airlines. How can loyalty to an airline be beneficial to a passenger? Would it guarantee a situation

\footnotetext{
*Associate Professor, School of Management and Economics, Xiamen University Malaysia, Malaysia.
} 
which can translate into huge revenues and growth for the firms or is loyalty rather a blind allegiance by a customer to a brand? What is the purpose of being loyal to a firm at all? If loyalty is indeed a feeling, an action, and above all, a clear sign of a brand's message resonating with their customers, then how does that work in the airline industry?

The paper takes cognisance of the above issues and examines the factors that affect customer loyalty and retention in the airline industry. It is particularly interested in ways in which passengers can be loyal to their choice of airlines, what the motivation is and how these passengers deal with situations like that. The paper subjects these to interrogation in order to determine how organisational life and the social understanding of individuals can lead to loyalty for a brand.

The study's premise is on a narrative inquiry. It uses the experiences of air passengers to provide the needed narrative. The resort to this is because a narrative provides an insight into two realms: (i) the realm of experience, where individuals detail their experience regarding certain events and deliberate on their subjective meaning onto these experiences; and (ii) the realm of narrative means (or devices) that are put to use in order to make (this) sense (Bamberg 2012). The unique thing about this approach is that the respondents were interviewed during chance meetings on a number of flights. The discussions were mainly centred on customer loyalty and its significance for both the airlines and customers.

The paper begins with an introduction to the issue under consideration. This is then followed by a review of the literature on customer loyalty, and then a focus on loyalty within the aviation industry. A brief is then devoted to the narrative inquiry and how it can be applied in the context of the study. A further explanation is offered for the approach adopted by the paper. Subsequently, the findings and discussions section is ushered in and the conclusion comes after that.

\section{Creating a Customer Focus Approach}

The continuous existence and growth of a company in today's complex business environment demands a broad vision as well as strong strategies aimed at customer relationship management (Baran et al. 2008). As such, companies need to understand and assess the potential of retaining customers since having loyal customers creates a situation in which organisations can develop an effective winning strategy (KPMG, 2016). That said, there is every indication that organisations become more successful when they embrace a customer-oriented approach in their deliberations (Narver et al. 2000). This is often done especially by creating a customer-centric company structure, in which the entire organisational activities are subject to the objectives of understanding, attracting and retaining the most valuable customers.

A customer-centric orientation, therefore, implies the mobilisation of resources primarily to identify, engage, acquire and retain by improving customer service and meeting their needs. According to Shah et al. (2006) it is the alignment of activities and resources of an organisation to effectively search for and respond to the everchanging needs of the customer, whilst building mutually beneficial relationships. It is above all, a strategic approach that enhances a business's competitiveness and 
increases its profitability (Deloitte 2020). Currently, companies are realising that customer centricity provides the best means to develop close and profitable relationships with their customers (Day 1999). This approach helps to ensure business sustainability and the alignment of all aspects of the relationship with customers in a way that delivers true competitive advantage for the business and also engages their loyalty (Jorgenson 2015).

\section{Seeking Loyalty among Customers}

The use of loyalty programmes has become quite popular now as a means to encourage customer loyalty. Managers of organisations typically believe that it is desirable and expected for a properly executed loyalty rewards programme to increase usage of company's product or service offering (O'Brien and Jones 1995). Loyalty programmes have, therefore, become a key component of customer relationship management (Kivetz and Simonson 2003). Henderson et al. (2011, p. 58) have defined a loyalty programme as 'any institutionalised incentive system that attempts to enhance consumers' consumption behaviour over time. According to Sharp and Sharp (1997), they are structured marketing efforts that reward and therefore encourage loyal buying behaviour, which is potentially beneficial to the firm.

Many researchers have acknowledged the significance of loyalty in service industries (Asuncion et al. 2004). Gomez et al. (2006) believe loyal customers are highly attractive to businesses because they are less price sensitive and require a lower effort to communicate with. Hence, in a bid to strengthen relations with their customers, organisations have begun to show renewed interest in customer loyalty programmes (Deloitte 2020). This has come to the fore because customer loyalty is a proven way not just to sustain market share but also to grow it (KPMG 2016).

Today, customer loyalty has become the new mantra for sustained growth and profitability. It is regarded as crucial for any organisation (Gravier 2013) since it is specific to inter-human relations. It is seen by Brink and Berndt (2008) as a customer's willingness to have a close relationship with a firm on a long-term basis. Tellis (1988) goes further to describe it as repeat purchasing frequency or relative volume of same-brand purchasing. Central to this notion of loyalty is that, loyalty is linked to some kind of gain or reward that induces someone to stay or repeat behaviour (Rai and Medha, 2013). But one aspect of this is that, it is not possible to show one line of action that drives customer loyalty, as it is heavily reliant on customers and their individual experiences with a brand (Hyken 2018). Memorable, enjoyable, novel and engaging consumption experiences are all seen as critical in customer experiences. Formation of customer loyalty is, therefore, a thorough process that involves a series of customers' evaluative judgements and other psychographic variables that stem from these service evaluations (Rai and Medha 2013). 


\section{Types of Loyalty Programmes}

Loyalty programmes are now used in many areas of business. They are structured in such ways that they provide the issuance of membership cards like: loyalty cards, rewards card, advantage card or club card which all identify the card holder as a member in a loyalty programme. They reward and encourage loyal buying behaviour among consumers. A typical loyalty programme includes five elements; a database, an enrolment process, rewards, value-added or soft benefits and customer recognition (Arantola 2000).

\section{Loyalty Schemes in the Service and Leisure Industry}

There is mounting evidence that organisational structures are evolving toward closer alignment with markets, especially for firms that are implementing solutions, strategies, and/or with assertive customers that want a single point of contact (Day 1999). Large companies striving for increased market share, scale, and efficiency therefore, try to compensate for the loss of personal relationships by using database marketing or sophisticated market research techniques to target valuable customers (O'Brien and Jones 1995). The sheer size of certain companies requires that in order to draw in their most valuable customers, they should have in mind the principles of effective value sharing. This requires such companies to provide effective considerations to their best customers in order to maximise their loyalty (Kim and Park 2017). By this means, customers who generate superior profits for a company are given the opportunity to enjoy the benefits of that value creation (Jorgenson 2015). This, therefore, connects them more to the company and enhances their loyalty to it. Crucially, this involves rewarding those customers who have stayed faithful to the companies. Rewards can and do build customers' loyalty, and most companies now appreciate how valuable that loyalty can be (Meyer-Waarden and Benavent 2006).

The leisure and hospitality industry has strenuously used the loyalty system to reward its customers (Deloitte 2020). The industry which includes a broad category of fields such as lodging, food services, event planning, theme parks, transportation and other tourism-oriented products and services, have various loyalty systems for their customers ranging from reward systems for guests who stay in hotels and resorts for leisure purposes or frequent users of particular services, among others. The promotions of loyalty programmes have become quite common today to the extent that consumers are now so inured to offers promising them a variety of exclusive things (Pascual and Cain 2021). To this end, customers now have certain levels of expectations about the service and leisure industry in terms of what they stand to gain from their association with some of these service operators or even on airlines as frequent flyers (Deloitte 2020).

\section{Loyalty Schemes in the Airline Industry}

In the case of airlines, the rewards offered include frequent flyer programmes which comprise accumulation of flight miles for future redemption against 
discounted or cheap flight tickets, affiliation with star alliances, special rewards for frequent flyers and other perks. The homogeneity of airline services has forced customer service quality to emerge as a principal factor in gaining a competitive advantage within the industry (Narver et al. 2000. Many airlines are often keen to offer quality services that can differentiate them from their key competitors. The loyalty scheme has therefore been touted as a good means to reach out to customers (Arantola 2000, Narver et al. 2000).

As acknowledged by KPMG (2016), the success of an airline depends upon its knowledge of its customers and its ability to device marketing campaigns that can suit the preferences of target groups. A careful identification of the most important attributes of airline services that can satisfy the needs of passengers and also provide an understanding of the best way to achieve passenger loyalty, seem very paramount more than ever (Dolnicar et al. 2011). Hence, factors leading to loyalty and their consequences in terms of loyalty behaviours are worth looking into, in that, they stand to provide us with a clear understanding of what might lead to effective loyalty practices and also offer a concrete base for designing an effective loyalty programmes for the airline industry.

Numerous studies have been conducted in recent years attempting to understand people's choices of airline patronage (Dolnicar et al. 2011). These studies have been quite diverse (see Suzuki 2007). Many of these have tried to explain in one way or the other the airline and their loyalty programmes, how consumers make their choices regarding airline selections as well as the experiences people carry when they enjoy certain experiential offerings (Dolnicar et al. 2011). Varied reasons for the selection of airlines have often engaged our attention. Most of these have bordered on: price; safety record of airline, or lack of one; mileage accrual and benefits; on-board facilities; schedule, baggage allowances, recommendations from friends, among others (O'Connell and Williams 2005).

Suzuki (2007), meanwhile, has noted that the airline selection is a two-step process where consumers first select a subset of airlines in their choice set and then determine the winning airline in their second step. In terms of the factors that play a significant role in airline choice, Suzuki identifies the price of the air fare, frequency of flight services provided to the required destination and frequent flyer membership status. Indeed, airline selection attributes represent an impression that is created by diverse factors such as airline service and airline image, and may play a critical role in the decision making and motivation of passengers who select an airline (Kim and Park 2017). Therefore, for an airline to attract more passengers and remain competitive, a thorough understanding of the factors considered by passengers when selecting an airline is essential.

The varying levels of customer preferences in terms of the selection of airlines create the need for a more insight into this as there is now a strong demand for improved ways of delivering sustainable competitive advantage strategies due to the competitive nature of the airline industry (Siu et al. 2013). Whilst numerous factors play into each airline's ability to surpass their competitors, that consistency in terms of what customers expect, remains to be achieved. From an airline's perspective, providing service quality promotes competitive advantage and increases the prospect of enjoying ongoing passenger patronage and loyalty (Keller 
2013) yet, customer loyalty is quite intricate and dynamic, it is ever changing and evolving over time (Johnson et. al. 2006). Hence, in order to survive and grow, airlines ought to find the best means of satisfying and retaining their customers. How this can be done depends on a number of factors. A major factor though would be for a firm's service delivery vision and organisational culture to be designed to ultimately provide customer value to the passenger (De Meyer and Mostert 2011).

Loyalty or frequent flyer programmes can therefore be built to provide stronger links with customers by providing increased satisfaction and value to passengers (Kim and Park 2017). Loyal customers are deemed to be people who would be willing to pay more and are less likely to be swayed by the competition. Loyalty is, therefore, principally valued for its outcomes since it amounts to the behaviour put up by loyal customers (O'Brien and Jones 1995). Hence, many companies strive to build customer loyalty and for good reasons too. However, an aspect yet to capture the attention of airline officials is that, part of what makes true loyalty so powerful is that it is emotional, rather than rational (Taylor 2016). According to Taylor, emotional loyalty entails a deeper level of commitment to an airline brand because the emotional tie goes beyond economic incentives. He argues further that, the rational consumer only stays as long as a certain value is being provided, but an emotional customer is more likely to stick with a brand.

But loyalty hinges on mutuality and parties involved ought to take each other's interests into consideration ( $\mathrm{Li}$ 2015). The mutuality reinforces the position that one can be loyal to someone if that person is loyal to the other. In line with such expectations, we may assume that airlines from which passengers expect so much, might perform or pursue some good actions in line with the said expectations passengers have of them, so that they would have repeat custom from passengers. This implication is that businesses need to explore the concept of value more deeply so as to better understand what customers consider valuable to them (Jorgenson 2015).

\section{Methodology}

The methodology adopted for this research is a qualitative one. It is based on and reflects the researcher's chats with air passengers on various routes over a three-year period. Initially orchestrated as a routine chat often engaged in during the author's air travels between the UK and Asia, what emerged from this led to the development of a full study by the author. These were chance meetings with total strangers during walk-abouts on flights. These acquaintances were engaged during informal strolls during flights. Although discussions pertained to various issues, loyalty issues concerning air passengers, cropped up in the course of these chats. Experiences that resonate with each other led us to the connection the researcher had with the interviewees. It was as a result of this that the researcher decided to analyse the issue further. Through this means, it became possible to have an insight into air travellers engagement preferences from a point of lived experiences. 
The study's major aim was to explore various factors that serve as antecedents to customer loyalty development. It, therefore, delved into customers' experiences with regards to the airlines they tend to patronise and the kind of relationship or bond they form with the said airlines. There was nothing formal about this approach. It was rather a shared conversation that threw up a lot of issues for discussions. The narratives were captured through mental notes which the researcher took in the course of the conversations during the interactions from 2017 to 2019. The study grouped together the views of 23 travellers on the subject of loyalty within the airline industry. Majority of the travellers were opened to engaging with the researcher and their other seatmates.

Creswell (2008) has provided an outline of how a narrative research can be conducted. The first, he claims, is to identify the problem. The next stage is to elicit responses from the participant through interviews, conversations, written accounts, artefacts and recordings that will provide stories their experiences. The next part is to retell the story to create a chronology of events that may include story elements of characters, setting, problem, actions and resolution. Active collaboration between the researcher and participants was vital during the entire research process. The researcher then composed the story of the participants' experiences, as suggested by Creswell. Finally, the narrative account was validated to ensure it represents accurately as possible the participants' stories.

\section{Narrative Inquiry}

In recent years the popularity and practice of narrative research methods or inquiry has grown significantly (Philpott 2014). A number of qualitative, in-depth interviewing techniques have been designed to elicit explicitly narrative accounts (Hollway and Jefferson 2008). Narrative approaches have also found their way into business-related disciplines as well. They have been used in marketing studies (Schau and Muniz 2006) and organisation studies (Gabriel 2000) among others. A narrative, in the context of narrative inquiry, is a story about a significant event or experience in a person's life. Stories can be viewed as a window onto a knowable reality. The stories offer us an insight into the narrators' experiences as they recall them at the time of the interview.

Narrative inquiry is a way of understanding and inquiring into experience through "collaboration between researcher and participants, over time, in a place or series of places, and in social interaction with milieus" (Clandinin and Connelly 2000 , p. 20). It focuses on people's narratives or stories either about themselves or a set of events, so there is an emphasis on emplotment (historiography) and characters. It is based on the premise that, as human beings, we tend to understand and give meaning to our lives or things around us through story telling or narration (Andrews et al. 2008). Such an inquiry, has relevance for our knowledge of the world of human interaction as it gives expressions to people to speak of their intentions and other issues concerning human interactions.

Bruner (1987) has argued that people construct meaning; they also make sense, and engage in a social nature through 'narrative' by chronicling events. More particularly, the field of narrative research involves engaging analytically with the 
ways in which people make sense of meaning and experiences, within the wider context of our social world (Bruner, 1987). Narratives whether attained through particular elicitation techniques, such as interviewing or initiated through interactional settings, are typically the outcome of a research stance or orientation. Narrative inquiry dwells on how meaning is conferred onto experience, especially in narratives of personal experience. It falls within the realm of qualitative research procedures and is also seen both as a method and the phenomenon of study.

Analysis

According to Gehart et al. (2007) in a narrative inquiry, analysis (meaning making) occurs throughout the research process rather than being a separate activity carried out after data collection. The process of 'data gathering' and 'analysis' therefore becomes a single harmonious and organic process, a situation which the researcher applied. Polkinghorne (2007) also gives credence to this by explaining that narrative research, just like conventional research, most often involves two performances: (a) the collection of evidence and (b) the analysis or interpretation of the evidence.

In terms of the evidence provided by the interviewees, the study noted the explanation offered by Polkinghorne (2007) that the purpose of the validation process is to convince readers of the likelihood that the support for the claim is strong enough and that the claim can serve as a basis for understanding of and action in the human realm. Again, the study took cognisance of the fact that validating knowledge claims is not a mechanical process but is, instead, an argumentative practice. As Polkinghorne (2007) explains, narrative researchers do not ask readers to grant validity to their claims only when they reach a level of near certainty about a claim, rather, readers are asked to make judgements on whether or not the evidence and argument convinces them at the level of plausibility, credibleness of the worthiness of a research knowledge claim in readers of the research. The argument here is that, it is the readers who make the judgment about the plausibility of a knowledge claim based on the evidence and argument for the claim reported by the researcher. Thus, as Polkinghorne (2007) reiterates, the confidence a reader grants to a narrative knowledge claim is a function of the cogency and soundness of the evidence-based arguments presented by the narrative researcher.

\section{Results}

The question of loyalty seemed a contentious one with the respondents. Whilst a considerable number of the respondents $(83 \%)$ deemed the loyalty programme as very interesting, attractive and worthy of note, there were varied reasons that called for the repudiation of the programme. Some even claimed whilst some airlines faithfully honour their promises, others reneged on them. Again, the respondents noted that such programmes lack transparency and that claiming rewards is so cumbersome to them. Faced with how the airlines operate these schemes, all the 
respondents felt the issue of loyalty has not been properly positioned in the best interest of passengers.

Whilst admitting that loyalty is reciprocal, they, however, insisted that the expected reciprocity has not been forthcoming from the airlines. Many respondents $(95 \%)$ stated that the airlines are more business-oriented to the extent that all they care about is to make a sound profit on their business, rather than reciprocating the gesture by customers. One respondent noted: "If the airlines are keen to ensure our loyalty then, they also ought to be loyal to us too." Another queried, "do you know the number of times I have to fly with the airline of my choice before I can even get to be rewarded? It is so ridiculous." The respondents were unanimous in their belief that reciprocal loyalty should become a new standard for effectively acquiring and retaining customers. They believe that the loyalty programme, for now, is so one-sided as it is only the passengers who are duly showing their loyalty to the airlines more than anything else.

In explaining further their perplexity, the respondents argued that since airlines demand loyalty, they (airlines) should, in turn, show reciprocity by also working in the best interest of passengers and by reducing ticket prices whenever possible for loyal passengers. The complaint was that ticket prices go up astronomically during the peak season, irrespective of whether one is a loyal passenger or not. 'How can we be loyal to them when they raise their fares during the time that they know we'd need their services so badly? They saw this as an act of betrayal which is only meant to make more money from them. "I can't even travel with the kids when they are on holiday because this is the time that the airlines also increase their fares," noted another respondent. Respondents said ticket prices are one of most salient economic exchange factors that a traveller will consider when selecting an airline. They gave credence to the fact that the success of low cost carriers demonstrates the importance of ticket prices and therefore when the major airlines increase their tickets prices, the issue of loyalty fizzles out in the eyes of a number of passengers.

There was also a huge concern about the perceived devaluation of the reward system. The complaint here was that fewer miles per flight are awarded and that unless one buys high-priced tickets, it is quite impossible to get more mile add-ons and eventually use that to buy a ticket. Many claimed the frequent flyer programme has become ridiculously useless. Not surprisingly, they all carried the notion it is quite good to look around and find out which airlines are offering the best prices at a point in time, rather than sticking to a particular airline on the basis of loyalty.

Many felt their loyalty is not being valued. Again, there was this notion that loyalty is an obsolete concept. Some even complained that the airlines have no 'souls or morals' and, therefore, do not care if they rip-off the customer. "Simply put, in this day and age, there is no reason to be loyal to one airline," many stated. The common refrain from the respondents was that since airlines are not doing anything to earn passengers' loyalty, passengers therefore should not show any dedication to them.

The frequency and nature of the changes to the loyalty programmes by the airlines also came up for discussion. Whilst varied views were expressed on this, what emerged was that normally much information is not provided if and when the 
airlines make some changes in that regard. In many cases, programme changes, invariably make it harder to earn miles, obtain better seats without paying some upcharge, and require even more miles to get the free trips or upgrades to premium cabins that travellers seek.

The narratives also provided an indication that the customer's perception of value is individualised and dependent on context and circumstances. What to one customer represents great value could be seen differently from the other's point of view. What a few of the respondents adduced was that the use of menu cards issued on flights was unnecessary as passengers had less options when it came to food being made available on a flight. It also emerged that perceiving an airline as having a good reputation leads to the relatively highest behavioural loyalty for the said airline. Although a greater number of the respondents stated their preference for airlines with good safety records and comfort, they were forthright on what they thought is more important to them when it comes to patronising airline services. For these people, price runs as the major motivating factor. The price hikes deter them from serving their cherished airlines loyally. They argued that since there is so much homogeneity in the services offered by the airlines, the only clear difference among them today is the price. The study revealed that frequent flyer passengers are very sensitive to prices.

\section{Discussion}

The narratives produced revealing insights into a variety of lived experiences among the participants. The relational properties of narrative inquiry provided the researcher and participants with a means to connect with each other, and also, offered a broader understanding of the phenomenon under investigation. It was realised that the promotion of such narratives has the tendency to contribute to greater levels of service delivery by organisations as the stories recognise, firstly, the problems customers were faced with and then offered the requisite solutions as well. The narrative inquiry with its relational aspects provided an opportunity for the researcher to build a relationship with the participants over a longer period which led to the collection of 'hidden' concerns that otherwise might have been lost out during a shorter data collection time.

What emerged from the interactions was that consumers very much care about the moral compass of the airlines, their deliberations and deliveries. Since many passengers do not seem to see how morally good airlines are, they stated that the airlines' profit-orientation makes them quite greedy. The contention was that the airlines ignore the plight of passengers and always try to take advantage of them during the peak travel times.

Consumers today, indeed, expect this loyalty to go in both directions. There seems to be a disconnection, though, in how the airlines talk about loyalty. Whilst they want repeat custom, they always seem to forget that by raising their fares during the peak season, they hit their customers very hard that even loyal ones always have to look around to get cheaper tickets elsewhere. Besides, some airlines even charge their passengers extra amount when they go slightly beyond the 
baggage allowances. Meanwhile, changes in departure dates also attract more payments and after a period of inactivity, the mileage won by passengers is also wiped off within a couple of years if passengers do not travel with the said airlines. All these issues provide a refrain for passengers that they cannot have the best deals from their favourite airlines. Whilst passengers were in agreement with the fact that loyalty rewards programmes provide an opportunity to build, longer, stronger and deeper relationships with customers it, they also reinforced the notion that if this is not handled very well, then the disaffection this causes could be much more beyond repair and probably take much longer time for customer loyalty to be reinstated.

So what can airlines do with their loyalty programmes to earn greater trust? How can they create a sense of loyalty that is reciprocal, authentic, and emotional? It would be important for them to foster the response that is most likely to drive loyal behaviour. Ultimately, this should be inspired by a well-articulated shared purpose and motivated by a heartfelt desire to show appreciation for and to return kindness to customers.

\section{Managerial Implications, Limitations and Contributions}

The findings of this study have important implications for airline managers. First, it provides an intimation that customer loyalty is quite intricate and dynamic, ever changing and evolving over time. As such, airlines need to understand passengers much more since having and retaining loyal customers could create a situation in which organisations can be successful. It also highlights the critical importance of looking at the whole issue of customer loyalty programmes from another perspective, through the narratives of frequent flyers.

The study's uniqueness is that it uses narrative inquiry as its method of inquiry. This inquiry is based on the premise that a person's lived and told stories are who they are and are becoming and that these stories sustain them. This understanding shapes the need to negotiate avenues that respectfully represent participants' lived and told stories. It also brings to the fore the need for organisations to reflect on these viewpoints and to address any concerns inherent thereof. The paper makes the argument that narrative inquiry is well suited to service delivery research in general as it focuses its inquiry on the individual person's experience from a temporal, social and spatial point of view.

The findings throw more light on how customers feel about airline loyalty schemes in particular and service delivery in general and, thus, contributes to the understanding of customer loyalty as a critical determinant of customer's attitude and behaviour. It offers an opportunity for managers to realise that airline loyalty programmes can build stronger links with customers if there is increased satisfaction and value to these customers.

Whilst the study constitutes an important step towards developing a better understanding of drivers of airline loyalty, there are some limitations in it, which need to be addressed too. This could also provide an opportunity for further research. First, this study focuses on a small number of passengers that the author 
met casually. As such, it could be argued to some extent that that it would be difficult to generalise its findings. Hence, future studies can use a larger number and also seek the views of the airlines regarding the assertions made by the passengers. Again, given that narrative inquiry is a new methodology, some audiences could be unfamiliar with the criteria to judge and respond to narrative inquiry research texts. Nonetheless, the criteria for judging narrative inquiries follow from the definition of narrative inquiry and the conceptual frame for thinking narratively.

\section{Conclusion}

The study sought to determine whether loyalty programmes are gaining the requisite support from air passengers. It also explored whether passengers can be loyal to airlines and under what conditions this could prevail. Its findings suggest that although air passengers are prepared to forge closer ties with the airlines, they often see the airlines as reneging on their pledge to offer reciprocal terms of this loyal arrangement. Passengers, therefore, see this loyalty engagement as a onesided arrangement which airlines rather stand to benefit from. Such a viewpoint has made many passengers to adopt a half-hearted approach to the loyalty programme which the respondents primarily perceive as a means to be signees of the loyalty programmes rather than being loyal members of the airlines.

\section{References}

Andrews M, Squire C, Tambokou M (Eds.) (2008) Doing narrative research. London: SAGE Publications.

Arantola H (2000) Buying loyalty or building commitment? An empirical study of customer loyalty programmes. Helsinki, Finland: Swedish School of Economics and Business Administration.

Asuncion B, Martin DJ, Quintana A (2004) Model of customer loyalty in the retail banking market. European Journal of Marketing 38(1/2): 253-275.

Bamberg M (2012) Narrative analysis. In Cooper (ed.), APA Handbook of Research Methods in Psychology, volume 2, 77-94. Washington, DC: APA Press.

Baran RJ, Galka RJ, Strunk DP (2008) Principles of customer relationship management. Mason, OH: Thomson South-Western.

Brink A, Berndt A (2008) Relationship marketing and customer relationship management. New York: Juta Academic.

Bruner J (1987) Life as a narrative. Social Research 54(1): 11-32.

Clandinin DJ, Connelly FM (2000) Narrative inquiry: experience and story in qualitative research. San Francisco: Jossey-Bass.

Creswell JW (2008) Narrative research designs. In educational research: planning, conducting, and evaluating quantitative and qualitative research, 3rd Edition, 511550. Upper River, NJ: Pearson Education Inc.

Day GS (1999) The market-driven organisation. New York: Free Press. 
De Meyer CF, Mostert PG (2011) The influence of passenger satisfaction on relationship formation in the South African domestic airline industry. South African Journal of Business Management 42(4): 79-87.

Deloitte (2020) Deloitte digital. Retrieved from: https://www.deloittedigital.com/content/ dam/deloittedigital/us/documents/blog/blog-20200618-airlines-hospitality-covid.pdf. [Accessed 20 August 2021]

Dolnicar S, Grabler K, Grun B, Kulnig A (2011) Key drivers of airline loyalty. Tourism Management 35(5): 1020-1026.

Gabriel Y (2000) Storytelling in organizations: facts, fictions, and fantasies. Oxford: Oxford University Press.

Gomez BG, Arranz AG, Cillan JG (2006) The role of loyalty programmes in behavioural and affective loyalty. Journal of Consumer Marketing 23(7): 387-396.

Gravier M (2013) Challenging or enhancing the EU's legitimacy? The evolution of representative bureaucracy in the Commission's staff policies. Journal of Public Administration Research and Theory 23(4): 817-838.

Henderson CM, Beck JT, Palmatier RW (2011) Review of the theoretical underpinnings of loyalty programmes. Journal of Consumer Psychology 21(3): 256-276.

Hollway W, Jefferson T (2008) The free association narrative interview method. In L Given (ed.), The SAGE Encyclopaedia of Qualitative Research Methods, 286-315. Thousand Oaks, CA: SAGE Publications.

Hyken S (2018) Customer experience is the new brand. Forbes.

Johnson MD, Herrmann A, Huber F (2006) The evolution of loyalty intentions. Journal of Marketing 70(2): 122-132.

Jorgenson E (2015) Why value creation is the foundation of business: how to define it, measure it, and manage it. Evergreen.

Keller, K.L. (2013) Building, measuring, and managing brand equity, 4th edn., Essex, England, Pearson.

Kim S-B, Park J-W (2017) A study on the importance of airline selection attributes by airline type: an emphasis on the difference of opinion in between Korean and overseas aviation experts. Journal of Air Transport Management 60(May): 76-83.

Kivetz R, Simonson I (2003) The idiosyncratic fit heuristic: effort advantage as a determinant of consumer response to loyalty programmes. Journal of Marketing Research 40(4): 454-467.

KPMG (2016) Is it time to rethink loyalty programmes? Switzerland: KPMG.

Li C-Y (2015) Switching barriers and customer retention. Journal of Service Theory and Practice 25(4): 370-393.

Maneenop S, Kotcharin S (2020) The impacts of COVID-19 on the global airline industry: an event study approach. Journal of Air Transport Management 89(Oct): 101920.

Meyer-Waarden L, Benavent C (2006) The impact of loyalty program on repeat purchase behaviour. Journal of Marketing Management 22(1): 61-88.

Narver JC, Slater SF, MacLachlan DL (2000) Total market orientation, business performance, and innovation. Cambridge, MA: Marketing Science Institute.

O’Brien L, Jones C (1995) Do rewards really create loyalty? Harvard Business Review 73: 75-82.

O'Connell JF, Williams G (2005) 'Passengers' perceptions of low cost airlines and full service carriers: a case study involving Ryanair, Aer Lingus, Air Asia and Malaysia Airlines. Journal of Air Transport Management 11(4): 259-272.

Pascual ME, Cain LN (2021) Loyalty programs: the vital safety feature for airlines to survive COVID-19. International Hospitality Review (Jun). 
Philpott C (2014) Using narrative research as a method in teacher education; a sociocultural approach. Teacher Education Advancement Network Journal 6(1): 12-19.

Polkinghorne DE (2007) Validity issues in narrative research. Qualitative Inquiry 13(4): 471-486.

Rai AK, Medha S (2013) The antecedents of customer loyalty: an empirical investigation in life insurance context. Journal of Competitiveness 5(2): 139-163.

Reichheld FF, Sasser WE (1990) Zero defections: quality comes to services. Harvard Business Review 68(5): 105-111.

Schau HP, Muniz Jr. AM (2006) A tale of tales: the Apple Newton narratives. Journal of Strategic Marketing 14(1): 19-33.

Sentence A (2012) What is the new normal for aviation, The new normal for airport investment. PwC.

Shah D, Rust RT, Parasuraman A, Staelin R, Day GS (2006) The path to customer centricity. Journal of Research Services 9(2): 113-124.

Sharp B, Sharp A (1997) Loyalty programmes and their impact on repeat-purchase loyalty patterns. International Journal of Research in Marketing 14(5): 473-486.

Siu NYM, Zhang TJF, Yau CYJ (2013) The roles of justice and customer satisfaction in customer retention: a lesson from service recovery. Journal of Business Ethics 114(4): 675-686.

Suzuki Y (2007) Modeling and testing the "two-step" decision process of travellers in airport and airline choices. Transportation Research Part E 43(1): 1-20.

Taylor M (2016) Loyalty is an emotion, not a transaction. eMarketer.

Tellis GJ (1988) Advertising exposure, loyalty, and brand purchase: a two-stage model of choice. Journal of Marketing Research 25(2): 134-144.

Wegner M, Budde F, Tranter P (2012) Surviving the squeeze - Winning strategies for a changing airline industry. Boston Consulting Group.

Zuidberg J (2014) Key drivers for differentiated airport passenger service charges. Journal of Transport Economics and Policy 48(2): 279-295. 